\title{
THE HORIZONS OF COGNITIVE PEDAGOGY
}

\author{
Dorota Siemieniecka \\ Bronisław Siemieniecki \\ Nicolaus Copernicus University Toruń, Poland
}

\begin{abstract}
The article addresses the problems of cognitive theory and research relevant to understanding the mechanisms of the learning process. It is meant to define the concept of cognitive pedagogy and emphasise the need for a new genetic/socio/cultural/media perspective, which in turn requires new research tools and increased attention to research results in the field of neuroscience. The authors define and characterise cognitive areas of cognitive pedagogy.
\end{abstract}

Keywords: cognitive pedagogy, neuro-didactics, media pedagogy, memetics, cognitive theories.

\section{Introduction}

Cognitive theories include areas of knowledge that are related to cognition, thinking, information-processing and problem-solving. Cognitive research focuses on perceptual-motor experience of reality and symbolic mental representation.

There are valuable elements of the theory and research in the history of pedagogical thought, which are drawn upon by the contemporary cognitive science. As early as in the early $20^{\text {th }}$ century, Maria Montessori (2005) emphasised the role of the training of senses in pupils' acquisition of both concrete and abstract concepts. She saw the role of the peripheral nervous system in the recognition of external stimuli. According to her, „spiritual life develops in connection with the central nervous system" (Montessori, 2005, 132). She also emphasised the social nature of learning.

A concept by Albert Bandura, belonging to a group of learning theories inspired by behaviourism, adequately describes this aspect of learning (through observation and modelling). It emphasises the role of cognitive interaction between humans and the surrounding environment (Bandura, 2011). Attention that learners must direct towards their behaviour and activity constitutes an important element that is emphasised by Bandura, who also stresses the role of repetition and motivation in the process. Studies on new-borns confirm that imitation-based learning skills are found in babies as early as between 12 - 21 days of age (Gardner, Kornhaber, Wake, 2011). Children can imitate mimic 
behaviour such as opening the mouth, tongue protrusion, provoking guardians to nonverbal behaviour (Trempała, 2011, 175) (research in this area was published in 2004 by Emese Nagy (Nagy, Molnar, 2004, 54-63). Other studies have also recognised that infants have a sense of objects and can make references to them (Spelke, 1991). Six-month-olds are able to differentiate between previously known and new objects (Trempała, 2011, 175) (as indicated by research results published in 2002 by Olivier Pascalis (Pascalis, de Haan, Nelson, 2002, 13211323). Children also have a sense of numbers, detect changes in them (Gardner, Kornhaber, Wake, 1990; Starkey, Gelman, Spelke, 1990; Wynn, 1992), as well as combine numbers with words (Gardner, Kornhaber, Wake, 1990). They also discriminate between classes of objects (Gardner, Kornhaber, Wake, 1990). Already 4-6-month-old infants differentiate phonemes in native and foreign languages (Trempała, 2011, 175), prefer to listen to speech of joyful character (Trempała, 2011, 176) (research in this area was performed in 2002 by a team of researchers: Leher Singh, James L. Morgan, Catherine T. Best (2004, 365-394). It is postulated in pedagogical literature that pedagogical scrutiny should encompass children within the period up to 3 years of age (Wenta, 2016). The results of tests on new-borns indicate that they recognise geometric patterns reminiscent of the shape of face (Johnson, Morton, 1991; Trempała 2011, 176) (interesting research was performed by Robert Frantz, (1961, 1963, 1965), John Johnson, Mark H. Morton (1991), Alan Slater (1998) David J. Kelly et al. (2005) they also scan objects vertically (downwards), also the phenomenon of emotional synchronicity (Trempała, 2011, 174) was detected; in the course of interactions with adults 3-month-old infants make use of visual contact (react smiling) (Farroni, Csiba, Simon, Johnson, 2002). It was also noted that sixmonth-olds direct their attention by means of following the gaze of adults (Moore, Dunham, 1995). Observations gained in the course of research, point to early emergence of adaptive mechanisms that provide orientation in important stimuli coming from the environment. These stimuli may be divided into visual and verbal. The learning process occurs in the course of information-processing within information channels, followed by the merge into a comprehensive verbal or visual model, and concluded with the final phase of the creation of new knowledge. This process is well described in Nine ways to reduce cognitive load in multimedia learning by Richard E. Mayer and Roxana Moreno (2000, 2003), who emphasise that the text- and image-based layers of messages merge with each other at the level of meaning. Integration of images and narratives impacts effective storage of information and facilitates the process of learning. At this point, the basics of the method by Maria Montessori is worth reflecting upon, who in her book Children's House $(2005,102)$ lists three stages of learning after Edouard Seguin (Gisolo, 2016) (which she defines as moments): association of sensory perception with the name (it is recommended to show colour, to call it 
by name and place a colour card in front of a pupil), familiarisation with an object through its name (requesting the child to provide a card with a certain colour), invoking a name by means of an object (Montessori, 2005, 102). The author also emphasises the importance of isolating and expanding the receptive potential of senses with regard to their intensity. Research, which scrutinised the correlation between IQ and the speed of information-processing and the reaction to a stimulus, confirms a connection between sensory sensitivity with the level of intelligence (Jensen, 1991, 59-70). Also, the dual coding theory by Allan Paivio (http://www.rit.edu) presupposes the existence of two cognitive subsystems: imagens - related to the representation and processing of images and logogens- related to the same processes in relation to words.

Research findings also point to varied developmental paces that are characteristic of every individual and attest to the development being dependent on innate characteristics, on the basis of which active construction of knowledge (Karmiloff-Smith,' 1992), based on language, numbers, understanding of the physical and socio-psychological world occurs (see also: J.D. Bransford, A.L.Brown, R.Cocking, How People Learn. Brain, Mind, Experience, and School, 1999). It may therefore be presupposed after David Ausubel (creator of the Theory of the preceding factor organising the material and learning activities - also known as a theory of assimilation) that the insofar acquired knowledge is an important part in the building of a hierarchy of concepts that facilitate orientation and construction of knowledge about the world. Interaction and understanding of the relationships between objects play an important role in the process of learning, i.e. ,we respond to the importance of what we observe and make its synthesis in our minds" (www.mimuw.edu.pl), a phenomenon pointed out by a gestalt theorist Wolfgang Köhler.

The theoretical positions presented above, together with conclusions based on research findings, may constitute a departure point for the presentation of research areas relevant to cognitive pedagogy.

\section{Research areas of cognitive pedagogy}

Cognitive pedagogy, sometimes wrongly referred to as neuro-pedagogy, is a branch of science which deals with the entirety of educational phenomena analysed from the position information-processing in the brain. It describes phenomena and educational processes, as well as education, all of which take into account genetic and environmental factors, both considered inseparably. The phenomena and processes occurring as a result of the impact of educational and didactic influence are explained on the basis of knowledge obtained from research on the structure and functioning of the human brain. Cognitive pedagogy also encompasses the problems of interconnections between 
environmental, social and cultural (human environment) as well as genetic conditions. It explains the conditions, processes and educational activities related to education on the basis of mechanisms involved in the collecting, processing, storing and presenting information.

Cognitive pedagogy is nowadays a rapidly growing sub-discipline of educational sciences. Due to its interdisciplinary character, it covers a number of areas, not only within the scope of interest of humanities. In order to understand its essence, it has become indispensable to find an answer to the question of why cognitive pedagogy is so important today. The answer would require a reference to knowledge on the communities of gatherers and hunters. In those days, human activities and pedagogical accumulation were decided, on the one hand, by nature, and on the other hand, by the genetic potential. It is around these two factors where discourse on the role and place of pedagogy in the modern world must be carried out. There is no doubt that Homo sapiens have a range of abilities related to genetics, such as: language skills, culture-creating skills, imitation, adaptation to extreme natural conditions, creation of tools, or the memory of the past. On this basis, inference about the present and the future is performed. A number of skills are strongly associated with the environment, such as culture. Genes had created conditions for the emergence of culture, and subsequently, ever since, culture has performed a process of natural selection that has been accelerating the development of human civilisation. This thesis, put forward by Michael Tomasello, made us aware of the importance of the connection between genetics and the environment. The same is true about the emergence of language, which is most likely a by-product of hominids' mental development within the process of evolution, i.e. in the wake of growth and development of the human brain or some other processes. There are numerous discussions around the emergence of language, which were described in the book by Bronisław Siemieniecki (2012) Introduzione alla pedagogia cognitive. In this context, research by Marc D. Hauser, Noam Chomsky and W. Tecumseh Fitch (2002) is very relevant, as it focuses on the search for the relationship between general abilities (intelligence) and language. In their paper The Faculty of Language: What is it, who has it, and how did it evolve? the authors write: ,it seems that the organisation of the human capacity for language is reminiscent of the genetic code - it is hierarchical, creative, recursive and basically unlimited" (Hauser, Chomsky, Fitch, 2002). This research raises questions about the scope of knowledge with which humans are born.

In pedagogy, transfer of knowledge and skills is one of the two most important areas addressed by the discipline. The use of knowledge discovered by others was of utmost importance for changes introduced by humans. Imitation has been essential for development, for the creation of innovation and adaptation of humans to extreme natural conditions that humans have been 
confronted with in the course of the past 200 thousand years. It has also had its impact on the creation of culture, which has played an important role in building communities, human groups and relationships existing in them. The authority of older people was rooted in the experience of many generations, which resulted in the transfer of knowledge and skills on to the next generation, as well as in their application in the processes of overcoming of mounting obstacles arising from dynamic changes present in nature. Older members of communities acted as computer disks in which information about past events was stored.

Activities that affected the development of tools created by man proved important for pedagogy. It was in them where a type of accumulation of knowledge was instigated by successive generations. Also, geographical conditions have not been without significance for the development of humans. The horizontal geographical design of Asia and Europe has been much more conducive to free flow of knowledge and skills between different communities than the vertical layout in North and South America.

In addition to historical preconditions of pedagogy, there also exist contemporary factors related to modern genetic modification, e.g. multiplication against the rules of nature, life extension, pharmacological changes in the psyche, emotions, impact on the personality, or exchange of a growing number of human organs. Not without its significance is human activity related to changing social environment. An example would be the world of the Internet. Unreality on a global scale is building a matrix, i.e. a mixture of reality and virtuality in conjunction with the world of large urban areas, where the majority of the human population resides, all of which is building an entirely new dimension of human functioning. The problem, however, lies in the fact that the gargantuan big cities function like artificial jungles. Their local living scale vastly differs from the primary determinants of human existence. It is an artificial, man-made world. As a result, Homo sapiens have left the natural world by building their own new surroundings. This means that modern pedagogy cannot be merely based on the past, but must embark on research on the nature of changes and the governing rules in the world that is remote from human activities in the past. Such an approach to pedagogy is significantly changing its optics, at the same time contributing to the formation of crises within it. On the one hand, we have the past and the scientific achievements based on research and observation of many generations; on the other hand, there are rapid technological and social changes that discontinue the insofar existing views and theories developed over the centuries. Understanding the dynamics of changes requires the adoption of new planes for considerations. This is possible from the perspective of cognitive pedagogy. In order to see and know more, we need to adopt a new research vision and thoroughly verify the insofar achievements of the discipline of pedagogy. It is not about criticism of the 
existing views and positions, but rather about the adoption of a new genetic/social/cultural/media perspective, which requires new research tools and additional attention to research findings within the area of neural sciences.

\section{Areas of cognitive pedagogy}

Having analysed the insofar research findings in the field of educational sciences and cognitive science, we may distinguish five basic areas of cognitive pedagogy:

- Neuro-didactics,

- Neuro-education,

- Memetics,

- Pedagogical anthropology,

- Media pedagogy

Neuro-didactics is a sub-discipline of cognitive pedagogy which includes:

Research and practice in the field of education, which seeks to optimise the teaching activities in order to achieve its goals.

- Problems of application of knowledge of individual capabilities and higher mental functions and in particular information processing in the human brain in the teaching process.

Neuro-didactics assumes that the teaching/learning process should be implemented on the basis of biological potential. This sub-discipline takes into account:

- regularities, mechanisms and developmental potential,

- real potential of the brain and preferences in learning,

- $\quad$ need for own improvement and drive to success.

- the nature of diversified intelligence and endless assortment of human personalities,

- developmental alchemy and school/life career paths,

- personal individual human development through self-improvement.

Neuro-education is a sub-discipline of cognitive pedagogy that deals with the regularities, mechanisms and the potential of human development, all explained by means of neuroscience. Knowledge about information-processing in the brain is then used to induce conscious, intended changes in human personality.

Memetics is a theory of cultural evolution that assumes the existence of units of cultural information labelled as memes. As a department of cognitive pedagogy, it deals with the influence of culture on educational theory and practice. In the analyses of pedagogical impact, the memetic theory plays an important role in uncovering factors determining pupils' behaviour. In the course of construction of educational standards, it facilitates the incorporation of selection mechanisms that are inherent in cultural evolution. Then it becomes 
easier to make difficult decisions of educational nature. Using memetic categories (replication variation and selection of replicators' potential) (see: R. Dawkins, Samolubny gen, 1996), cognitive pedagogy makes it possible to specify the scope and applicability of ideas, behaviours, styles or habits that are characteristic of students (pupils) within a given culture. As humans have an incredible ability to imitate and reproduce culture, memes are used in cognitive pedagogy ${ }^{1}$ (equivalents of genes in biology) to explain teachers' and pupils' actions in order to better perceive the dependencies inherent in the educational process.

Pedagogical anthropology, as a constituent of cognitive pedagogy, addresses human beings seen as creatures that are capable of being educated and in need of education. Humans remain in the focus of attention due to the fact that they are subjected to the processes of education. The experience of everyday life, which is composed of phenomena of educational reality, becomes a basic point of departure. When analysing these phenomena from the perspective of information-processing in the human brain, interpretation is possible, which in turn facilitates making correct pedagogical decisions, and therefore makes it possible to find a foundation for justification of pedagogical activities.

Media pedagogy is a pedagogical sub-discipline dealing with human communication assisted by the media, with its multidimensional analysis regarding the mechanisms of learning and education, instigated by the impact of the media on humans. It may therefore be assumed that media pedagogy deals with human communication with the media and through the media. As such, it covers five areas:

general education, dealing with: the media in social communication, problems of the social nature of the media, the effects of communication in society, media institutions and mechanisms determining their programs, the concepts of media societies and their impact on education systems, educational systems and the media;

- media education, dealing with the process of teaching/education in all forms of education, training and self-education, media and IT training methodology;

information technology, addressing issues related to knowledge about the technological side of the media and their use in everyday life;

\footnotetext{
${ }^{1}$ In psychology, a meme is defined as a unit of cultural heritage that is analogous to a gene, i.e. internal representation of knowledge, whereas in biology, Richard Dawkins, described the term meme as a basic unit of cultural transmission, i.e. imitation. Daniel Dennett assumes that a meme is ,, complex notion that assumes a distinctive, easy to remember shape. Material manifestations of memes are means of its dissipation”.
} 
- computer diagnostics and pedagogical therapy, aiming at the application of information technology in various areas of special education with the use of computers in the process of rehabilitation and social reintegration;

- the media in the human world, dealing with different bio-sociocultural circumstances and civilisational aspects of the use of the media in the process of learning (Siemieniecki, 2007).

In conclusion, it should be emphasised that the discussion on the area of media communication seen from the perspective of information-processing in the human brain constitutes the most valuable part of media pedagogy. Currently, research on the use of the media, in cooperation with the human brain, constitutes the most interesting component of cognitive pedagogy.

\section{Conclusions}

The vaguely presented areas of cognitive pedagogy do not exhaust the scope of relevant problems. However, they make it possible to recognise some fundamental planes of pedagogical discourse within future education. Specific currents of cognitive pedagogy remain as an open question, an example being cognitive didactics, which brings together the knowledge of neuro-didactics and cultural conditions of the educational process. Definition of its place within cognitive pedagogy requires, on the one hand, deeper theoretical analyses, and on the other hand, further empirical research. Despite conceptual problems and difficulties in the fine-tuning of the specific areas of disciplines, growing importance of this discipline for didactic and educational processes has been clearly discernible.

\section{References}

Bandura, A. (2011). Social Learning Theory. Retrived from http://www.simplypsychology.org/bandura.html

Bransford, J.D., Brown, A.L., Cocking, R. (1999). How People Learn. Brain, Mind, Experience, and School. Retrived http://www.colorado.edu/MCDB/LearningBiology/ readings/How-people-learn.pdf

Dawkins, R. (1996). Samolubny gen. Warszawa: Prószyński i S-ka.

Farroni, T., Csiba, G., Simon, F., Johnson, M.H. (2002). Eye contact in human from birth. Retrived http://www.pnas.org/content/99/14/9602.full

Frantz, R. (1963). Pattern vision in newborn infants. Retrived http://home.fau.edu/ lewkowic/web/Fantz\%20Infant\%20Preferece1963.pdf

Frantz, R., (1961). The origin of form perception. Scientific American, 204(5), 66-72.

Frantz, R., (1965). Visual perception from birth as shown by pattern selectivity. New Issues in Infant Development, vol. 118, 793-814. 
Gardner H., Kornhaber M.L., Wake W.K. (2001). Inteligencja: wielorakie perspektywy. Warszawa: WSiP.

Gisolo, G., (2016). Biographical Highlights. Retrived from http://www.learningtogive.org/ resources/montessori-maria

Hauser, M.D., Chomsky, N., Fitch W.T. (2002). The Faculty of Language: What is it, who has it, and how did it evolve?. Science, 12/22, no. 298 (5598), 1569-79.

Jensen, A. R. (1991). Speed of elementary cognitive processes: A chronometric anchor for psychometric tests. Psychological Test Bulletin, no. 4, 59-70.

Johnson M.H., Morton J., (1991). Biology and Cognitive Development:The case of face recognition, Oxford: Blackwell.

Johnson, M.H., Morton J. (1991). Biology and Cognitive Development: The case of face recognition. Oxford: Blackwell.

Karmiloff-Smith, A. (1992). Abnormal behavioral phenotypes and the challenges they pose to Connectionist models of development. Technical Reports in Parallel Distributed Processing and Cognitive Neuroscience. Carnegie Mellon University.

Kelly, D.J., Quinn, P.C., Slater, A.M., Lee, K., Gibson, A., Smith, M., Ge, L., Pascalis, O. (2005). Three-month-olds, but not newborns, prefer own-race faces. Developmental Science, 8 (6), 31-36.

Mayer, R.E., Moreno, R. (2000). Aids to computer-based multimedia learning. Retrived from http://www.psychology.mcmaster.ca/bennett/psy720/readings/m1/m1r3.pdf

Mayer, R.E., Moreno, R. (2003). Nine Ways to Reduce Cognitive Load in Multimedia Learning. Retrived from http://portal.ou.nl/documents/25460761/0/Mayer+\% 26\%20Moreno+2003+-+EPigxrG8CM.pdf

Montessori, M. (2005). Domy dziecięce. Warszawa: Wydawnictwo Akademickie „ŻAK”.

Moore, C., Dunham, P.J. (1995). Joint attention: Origins and role in development. New York: Lawrence Erlbaum, Hillsdale.

Morton, J., Johnson, M.H. (1991). CONSPEC and CONLERN: A two-process theory of infant face recognition. Psychological Review, vol. 98, no. 2, 164-181. Retrived from http://www.researchgate.net/profile/John_Morton4/publication/21107526_CONSPEC_a nd_CONLERN_a_two-

process_theory_of_infant_face_recognition/links/5409933c0cf2187a6a6fa0ad.pdf

Nagy, E., Molnar, P. (2004). Homo imitants or homo provocans? Human imprinting model of neonatal imitation. Infant behavior and Development, no. 27, 54-63.

Paivio, A., Dual Coding Theory: Retrospect and Current Status. Retrived http://www.rit.edu/ cos/smerc/journalpapers/Paivio_Dual_coding_theory_review.pdf

Pascalis, O., de Haan, M., Nelson, C.A. (2002).Is face processing species specific during the first year of life. Science, 296, no. 5571, 1321-1323.

Retrived from http://www.rit.edu/cos/smerc/journalpapers/Paivio_Dual_coding_ theory_review.pdf

Siemieniecki, B., (2012). Introduksjon til kognitiv pedagogikk. Tromsø, Norway: Arktisk Forlag.

Siemieniecki, B. (2012). Introduzione alla pedagogia cognitiva. Roma: Armando Editore.

Siemieniecki, B., (2007). Przedmiot i zadania mediów w komunikacji. In: B. Siemieniecki (Ed.), Pedagogika medialna. Warszawa: PWN.

Singh, L., Morgan, J.L., Best, C. (2004). Infants' listening preferences: Baby talk or happy talk. Infancy, no. 3, 365-394.

Slater, A., Perceptual development. Visual, Auditory and Speech Perception in Infancy, Psychology Press Publisher, UK 1998. 
Spelke, E.S. (1991). Physical knowledge in infancy : Reflections on Piaget's Theory. In S. Carey, R. Gelman (Eds.), Epigenesis of mind: Studies in biology and cognition. New York: Hillsdale, Lawrence Erlbaum Associates Publishers.

Starkey, P., Gelman, R., Spelke, E.S. (1990). Numerical abstraction by human infants. Cognition, no. 36, 97-127.

Strelau, J. (1987). O inteligencji człowieka. Warszawa: Wiedza Powszechna.

Teorie kształcenia. (2016). Retrived from www.mimuw.edu.pl/ eler/wyklady/01wyklad.ppsx Trempała, J. (2011). (Ed.), Psychologia rozwoju człowieka. Warszawa: PWN.

Wenta, K., (2016). Kognitywistyka $w$ multimedialnych $i$ sieciowych systemach informacyjnych. Retrived http://www.zsi.pwr.wroc.pl/zsi/missi2002/pdf/s102.pdf

Wynn, K. (1990). Children's understanding of counting. Cognition, vol.36/2, 155-193.

Wynn, K. (1992).Children's acquisition of the number words and counting system. Cognitive Psychology, vol. 24/2, 220-251. 